\title{
Effect of Training and Motivation on Job Performance of Library Personnel of University of Lagos, Lagos State, Nigeria
}

\author{
Ezinwanyi Madukoma, Victoria Ozioma Akpa, Ugochi N. Okafor \\ Babcock University, Ilishan-Remo, Nigeria \\ Email: mezinwanyi@yahoo.com, voakpa@yahoo.com, ugochiokafor@yahoo.com
}

Received 5 June 2014; revised 15 July 2014; accepted 20 August 2014

Copyright (C) 2014 by authors and OALib.

This work is licensed under the Creative Commons Attribution International License (CC BY). http://creativecommons.org/licenses/by/4.0/

\section{Abstract}

The study investigated the effect of training and motivation on job performance of library personnel of University of Lagos, Lagos State, Nigeria. Observation show that library users frequently complain that library staff do not attend to their queries properly. This phenomenon could be attributed to lack of training and motivation to the library personnel. Survey method was used in the study. The population comprised 135 library personnel in the University of Lagos. Total enumeration was employed as sample size. Out of 135 copies of questionnaire distributed to the respondents, 91 were completed and returned. Analysis was done based on the returned copies of the questionnaire. Statistical methods used were frequency count (presented in tables), mean and standard deviation. The result of the study showed that training motivates library personnel in University of Lagos to do their jobs. In turn, this enhances their performance on the job. Therefore, the study recommends that regular training should be given to library personnel, not only in the University of Lagos but elsewhere, as this would result in increased productivity, availability of skilled workforce and personal growth.

\section{Keywords}

Training, Motivation, Job Performance, Library Personnel, University of Lagos, Nigeria

Subject Areas: Psychology, Sociology, Library Science, Social Science

\section{Introduction}

In the present global economy, most employers have realized that for their organization to compete and be successful, the performance of their employees is very important. For this reason, many employers of labour put 
several mechanisms in place to ensure that optimum job performance is achieved. Job performance, according to Munchinsky, is the set of an employee's behaviour that can be monitored, measured, and assessed at individual level. These behaviours are also in agreement with the organizational goals [1]. Hence, Saetang, Sulumnad, Thamppitak and Sungkaew believe that job performance is a human behaviour which the result is an important factor for individual work effectiveness evaluation [2]. Therefore, it is argued that optimum performance within the library is related to achieving the quality, quantity, cooperation, dependability and creativity of the library personnel. Job performance needs to comply with knowledge acquisition, skills development and of course good personal values, which come as a reward of the employee having an annual salary increase and promotion. It is expected that certain measures need to be put in place to encourage and motivate workers to perform up to expectation; these measures include but not limited to training.

Training, according to Cole, is a learning activity which is directed towards the acquisition of specific knowledge and skills for the purpose of an occupation or task [3]. In the same vein, De Cenzo and Robbins posit that training is basically a learning experience, which seeks a relatively permanent change on individual's skills, knowledge, attitudes or social behavior [4]. This implies that there is need to improve employee's skills and knowledge so that he or she becomes efficient to work on both present and future jobs and tasks. A prominent benefit of training is that it eliminates risks in organizations. Since the trained personnel are efficient, they are able to make better use of the organizations property, thereby reducing and avoiding waste. Training would help employees to master knowledge, skills, behaviors, sense of self-worth and confidence which in turn motivate them to perform efficiently and improve on the performance of the organization.

Motivation, on the other hand, is that guiding principle that enables people to stay focused on the path to success, regardless of the challenges they encounter in their attempts to achieve personal and professional goals and targets [5]. Generally, human beings long to be motivated in other to perform effectively. According to Adeyemo, motivation is a human psychological characteristic that contributes to a person's degree of hard work and trust. It is seen as something which is good, and one cannot feel good with oneself if he or she is not motivated. It is a basic psychological process, which is also considered as predictor of job performance [6]. As Akpa aptly argues, "Employee motivation is very important and vital in organization and in any job if people are to give their best" [7]. Thus, the determinants of optimum job performance are training and motivation. It is therefore important that appropriate training should be given to library personnel in order to motivate them for efficiency and optimum performance. However, it is important to state that past studies have shown other factors that could motivate individual employees, especially as revealed in Herzberg's two-factor theory [8]. But the focus of this study is on how training motivates library employees to perform their jobs.

\subsection{Statement of the Problem}

The library helps in providing and solving the information needs of different users: students, lecturers, and other researchers. This is done through the assistance of the library personnel at various levels. However, research and observation show that most times users complain that library staff do not attend to their query properly, which could be attributed to lack of training and motivation which as a result, affects their job performance. This study therefore, seeks to investigate the effect of training and motivation on job performance of library personnel in University of Lagos, Nigeria.

\subsection{Objectives of the Study}

The specific objectives of the study are to:

1) Find out if training is given to library personnel in University of Lagos.

2) Establish the type of training given to library personnel at University of Lagos.

3) Assess the type of training needed by library personnel at the University of Lagos.

4) Ascertain the preferred training by library personnel in University of Lagos.

5) Find out to what extent training motivates library personnel to perform their job in University of Lagos.

6) Find out the perceived impact of training and motivation on the job performance of library personnel in University of Lagos.

7) Find out how job performance of library personnel is measured. 


\section{Literature Review}

\subsection{Training and Job Performance of Library Personnel}

Training is defined as a short term process utilizing a systematic and organized procedure by which non-managerial personnel learn technical knowledge and skills for a definite purpose [9]. When employees are trained, they get their skills improved and develop progression in their skills that will enhance their productivity and performance and subsequently complete their tasks on time. Moreover, Iqbal, Nabi, Muneer, and Anuar contend that training outputs ought to emphasize performance, not just learning, which is the employer's expectations from training; that is why training has such a pivotal role in organizations. The employees have several expectations associated with training as well so full of career expansion opportunities [10]. Training can be motivator for personnel to enhance dedication to organizational performance.

Yalokwu emphasized the need for training by stating that it is important that all employees be inducted into training programmes to improve their job-related knowledge, skills and performance [11]. Madukoma and Nwosu stated that there are many levels of training including orientation, initial job training. They further observe that while some are received by every employee, others are customized to meet individualized employee needs [12]. Obi and Zakari identified in-house service training, workshops, seminars, conferences, job rotation, continuing education, personalized training, orientation, internships, on-the-job coaching as types of training [13]. Yalokwu broadly classified methods of training as on-the-job, off-the-job, stimulation methods and information presentation methods [11]. All these types of training help to equip staff as well as motivate them to perform well on their jobs.

Daw has tressed that in view of the importance of staff training in university libraries, libraries should ensure regular training development of all staff; encourage the illiterate staff to attend adult literacy classes to ensure their retention and progress; and all staff, where appropriate, to go for higher education [14]. Similarly, American Association of Law Libraries emphasized that the library personnel is responsible for the maintenance of the library and therefore is required to go through some training to equip him or her for the task ahead [15]. Thus, training of library personnel is crucial for the development and success of the library.

\subsection{Motivation and Job Performance of Library Personnel}

According to Hackett, motivation is the process that starts with psychological deficiency or need that activates a behavior or a drive that is aimed at a good incentive [16]. Hence, Abonam ascertains that it is widely recognized that motivation plays a role in keeping an employee performing his/her best in any task assigned. Motivated employees help organization survive and are more productive. Therefore, to be effective, managers need to motivate employees within the context of the roles they perform; and the achievement of individuals and organizational goals are independent process linked by employee work motivation [17]. Simlarly, Stueart and Moran see motivation at work as the sum of processes that influence the arousal, direction, and maintenance of behaviours relevant to work setting [18]. In the opinion of Akpa, "In as much as it is almost impossible for the management of today's complex organizations to satisfy all their employees, they should strive to satisfy and motivate a majority of their employees so as to enhance job satisfaction, increase productivity and reduce the rate of employee turnover" [19]. Thus, library personnel should be motivated by giving them training in different environments and circumstances. These in effect will help them acquire different skills that will boast their job. Consequently, Campbell posits that in order to ensure job and career security, it is important for employees to continually update and expand their work experiences and job skills [20]. These are likely to be achieved when the worker is equipped through training.

There are many factors that can motivate personnel to put their maximum in their jobs; these include but not limited to good salary packages, conducive working environment, regular promotion, good communication climates, staff training and development. It is important to note that all personnel cannot be motivated by the same motivating factor and have the same motivating effect at a time. Hence the focus of this study is on training as a precursor to motivation and job performance.

\subsection{Job Performance of Library Personnel}

Job performance, according to Yaya, refers to the work activities carried out by the worker towards the achievement of organizational goals. It is an act of fulfilling one's obligation to the organization. This depends 
not only on the amount of physical effort exerted but also on the person's mental ability [21]. This implies that employees will put in their best in performing their jobs if they are motivated perhaps through training. Furthermore, Johari and Yahya stated that job performance has become one of the significant indicators in managing organizational performance. Moreover, growing emphasis has been given on employee's job performance as a source of competitive advantage to promote responsiveness in enhancing overall organizational effectiveness [22]. Afful-Bronistated that individual performance is generally determined by three factors; namely, abilitythe capability to do the job; work environment - the tools, materials and information needed to do the job; and motivation - the desire to do the job [23]. Employees that are given required training would be equipped for the job in all ramifications.

\section{Methodology}

Descriptive survey research design was employed to carry out this study. The population of study cut across all strata of professionals, para-professionals and library assistants at the university of Lagos library giving a total number of 135 staff. The sampling technique used was total enumeration, thus involved the entire population of the study. A structured questionnaire was the instrument used for data collection. One hundred and thirty-five (135) copies of the questionnaire were distributed to the library staff of University of Lagos. Out of this number, ninety-one (91) were duly completed and retrieved. All retrieved copies were valid and used for data analysis.

\section{Presentation of Result}

Data analysis was based on the retrieved copies of the questionnaire. Descriptive statistics, such as frequency and percentage presented in tables, mean and standard deviation were used in reporting the result. This is shown in Table 1 Demographic Information about the Respondents.

Table 1 reveals that there were slightly more female respondents (50.5\%) than male respondents (49.5\%) that participated in the study. There were more married respondents (71.6\%) than the single respondents (28.6\%). A majority of the respondents (40.7\%) were within the age bracket of 31 - 40 years. Although respondents with working experience of 1 - 10 years (74.7\%) were in the majority, all the respondents with working experience of 1 - 10 years (74.7\%), 11 - 20 years (11.0\%), 31 - 40 years (6.6\%), 21 - 30 years (5.5\%) respectively have the ability to respond to effect of training and motivation positively. More than half of the respondents (55.0\%) have Bachelor's degree (or its equivalent) and above.

Research Question 1: Is training given to library personnel in the University of Lagos?

Table 2 reveals that respondents agree that training is given to library personnel in the University, with the response rate of "Yes" (79.1\%) as the highest and "No" (20.9\%) with the lowest.

Research Question 2: What type(s) of training is mostly given to the library personnel in the University of Lagos?

Table 3 shows the type of training mostly given to the library personnel in the University of Lagos. In total, there were 7 questions that were used to describe the types of training given to library personnel in the University of Lagos, and amidst all, library personnel in the University received training mostly through workshops, job rotation, self-instruction and computer based training.

Research Question 3: What type of training is needed by the library personnel in University of Lagos?

Table 4 shows the type of training needed by the library personnel in University of Lagos. According to the table, the most needed type of training was conference attendance $(M=3.41)$, followed by workshops $(M=$ 3.18), and computer based training $(M=3.13)$. The least required training was coaching $(M=2.51)$. Thus, Table 4 indicates that conference attendance, workshops and computer based training are the training types mostly needed by library personnel in University of Lagos.

Research Question 4: Which type of training do you prefer most?

Table 5 reveals that workshops (31.9\%) is the most preferred type of training by the library personnel, computer based training (22.0\%), job rotation (15.4\%), conference attendance (13.2\%), coaching (9.9\%), classroom courses $(4.4 \%)$, while self-instruction ( $0 \%)$ is the least most preferred among the library personnel, it is not regarded as a training. It is vital that library administration see to it that staff training needs are met.

Research Question 5: To what extent does the type of training offered in the library motivate library personnel in the University of Lagos?

Table 6 reveals that the library personnel are motivated at large extent (38.5\%) with the type of training of- 
Table 1. Demographic information about the respondents.

\begin{tabular}{|c|c|c|c|c|}
\hline $\mathrm{S} / \mathrm{N}$ & Categories & Component & Frequency & Percentage \\
\hline \multirow[t]{3}{*}{1} & Gender & Male & 45 & 49.5 \\
\hline & & Female & 46 & 50.5 \\
\hline & & Total & 91 & 100.0 \\
\hline \multirow[t]{3}{*}{2} & Marital status & Single & 26 & 28.6 \\
\hline & & Married & 65 & 71.4 \\
\hline & & Total & 91 & 100.0 \\
\hline \multirow[t]{5}{*}{3} & Age & $21-30$ & 24 & 26.4 \\
\hline & & $31-40$ & 37 & 40.7 \\
\hline & & $41-50$ & 22 & 24.2 \\
\hline & & $51-60$ & 7 & 7.7 \\
\hline & & Total & 91 & 100.0 \\
\hline \multirow[t]{6}{*}{4} & Years of work experience & $1-10$ & 68 & 74.7 \\
\hline & & $11-20$ & 10 & 11.0 \\
\hline & & $21-30$ & 5 & 5.5 \\
\hline & & $31-40$ & 6 & 6.6 \\
\hline & & 41 and above & 1 & 1.1 \\
\hline & & Total & 91 & 100.0 \\
\hline \multirow{8}{*}{\multicolumn{2}{|c|}{5 Qualification educational qualification }} & SSCE & 21 & 23.1 \\
\hline & & NCE & 9 & 9.9 \\
\hline & & ND & 8 & 8.8 \\
\hline & & HND & 15 & 16.5 \\
\hline & & $\mathrm{BSc} / \mathrm{BLS} / \mathrm{BA}$ & 25 & 27.5 \\
\hline & & PGD & 2 & 2.2 \\
\hline & & MADEGREE & 8 & 8.8 \\
\hline & & Total & 91 & 100.0 \\
\hline
\end{tabular}

Table 2. Components Frequency Percentage

\begin{tabular}{ccc}
\hline Components & Frequency & Percentage \\
\hline YES & 72 & 79.1 \\
NO & 19 & 20.9 \\
TOTAL & $\mathbf{9 1}$ & $\mathbf{1 0 0 . 0}$ \\
\hline
\end{tabular}

Table 3. Type(s) of training mostly given to library personnel at University of Lagos.

\begin{tabular}{cccc}
\hline S/N & Components & Frequency & Percentage \\
\hline 1 & Workshop & 21 & 23.1 \\
2 & Job rotation & 17 & 18.7 \\
3 & Self-instruction & 12 & 13.2 \\
4 & Computer based training & 11 & 12.1 \\
5 & Conference attendance & 8 & 8.8 \\
6 & Coaching & 8 & 8.8 \\
7 & Classroom courses & $\mathbf{7}$ & 7.7 \\
& Total & $\mathbf{9 1}$ & $\mathbf{1 0 0 . 0}$ \\
\hline
\end{tabular}


Table 4. Type of training needed by library personnel in University of Lagos.

\begin{tabular}{cccccccc}
\hline S/N & Types of Training & SA (\%) & A (\%) & SD (\%) & D (\%) & Mean & Std.D. \\
\hline 1 & Conference attendance & $60(65.9)$ & $23(25.3)$ & $1(1.1)$ & - & 3.41 & 1.09 \\
2 & Workshops & $50(54.9)$ & $29(31.9)$ & $1(1.1)$ & $1(1.1)$ & 3.18 & 1.25 \\
3 & Computer based training & $49(53.8)$ & $29(31.9)$ & $1(1.1)$ & - & 3.13 & 1.31 \\
4 & Job rotation & $47(51.6)$ & $24(26.4)$ & $4(4.4)$ & $3(3.3)$ & 2.97 & 1.41 \\
5 & Self-instruction & $31(34.1)$ & $36(39.6)$ & $6(6.6)$ & $3(3.3)$ & 2.71 & 1.40 \\
6 & Classroom courses & $32(35.2)$ & $29(31.9)$ & $5(5.5)$ & $8(8.8)$ & 2.56 & 1.50 \\
7 & Coaching & $25(27.5)$ & $38(41.8)$ & $3(3.3)$ & $9(9.9)$ & 2.51 & 1.44 \\
\hline
\end{tabular}

Table 5. Type of training preferred most by library personnel.

\begin{tabular}{cccc}
\hline S/N & Components & Frequency & Percentage \\
\hline 1 & Workshop & 29 & 31.9 \\
2 & Computer based training & 20 & 22.0 \\
3 & Job rotation & 14 & 15.4 \\
4 & Conference attendance & 12 & 13.2 \\
5 & Coaching & 9 & 9.9 \\
6 & Classroom courses & 4 & 4.4 \\
7 & Self-instruction & 0 & 0 \\
& Total & $\mathbf{9 1}$ & $\mathbf{1 0 0 . 0}$ \\
\hline
\end{tabular}

Table 6. The extent to which training motivates library personnel.

\begin{tabular}{cccc}
\hline S/N & Extent of Training & Frequency & Percentage \\
\hline 1 & To a large extent & 35 & 38.5 \\
2 & To some extent & 43 & 47.3 \\
3 & Not at all & 7 & 7.7 \\
& Total & $\mathbf{9 1}$ & $\mathbf{1 0 0 . 0}$ \\
\hline
\end{tabular}

fered in the library, to some extent (47.3\%) and the least is Not at all (7.7\%). This finding indicates that training given to library personnel in University of Lagos does actually help them to put in their best in their jobs, though, to some extent. Perhaps this is the reason Iqbal, Nabi, Munner and Anuar contend that training outputs ought to emphasize performance, not just learning which the employee's expectation from training is [24].

Research Question 6: What is the perceived impact of training and motivation on job performance of library personnel in the University of Lagos?

According to Table 7, training helps library personnel to be more creative in their line of work $(M=3.59)$ ranking the highest. This is followed by responding to needs and feelings of different people in difficult situation $(M=3.47)$ and so on. The result indicates that training equips library personnel skillfully and psychologically. This finding is supported by Stueart and Moran who affirmed that training influences the arousal, direction, and maintenance of behaviours relevant to work setting [18].

Research Question 7: How is the library personnel in university of Lagos assessed?

In Table 8, performance measures of library personnel in University of Lagos indicate that they were more punctual at work $(M=4.57)$, while leadership quality $(M=4.20)$ and quality of work output $(M=4.20)$ followed. Problem solution ability ranked least $(M=3.85)$. Nevertheless, it is significant to point out that the mean scores of all ten performance factors measured were above $3.50(M>3.50)$, indicating that on the overall, the performance of the library personnel in the University is above average. 
Table 7. Perceived impact of training on job performance of library personnel.

\begin{tabular}{cccccccc}
\hline S/N & \multicolumn{1}{c}{ Question } & SA\% & A\% & SD\% & D\% & Mean & Std.D \\
\hline 1 & Training helps me to be more creative & $66(72.5)$ & $20(22.0)$ & $1(1.1)$ & $1(1.1)$ & 3.59 & 0.85 \\
2 & $\begin{array}{c}\text { It helps me to respond appropriately to the needs and } \\
\text { feelings of different people in difficult situation }\end{array}$ & $54(59.3)$ & $32(35.2)$ & $2(2.2)$ & - & 3.47 & 0.83 \\
3 & $\quad$ Training helps me to work with others & $55(60.4)$ & $28(30.8)$ & $5(5.5)$ & - & 3.45 & 0.87 \\
4 & $\begin{array}{c}\text { Training helps me in ensuring that jobs within the areas of } \\
\text { specific responsibility are completed in a timely manner }\end{array}$ & $52(57.1)$ & $30(33.0)$ & $4(4.4)$ & $3(3.3)$ & 3.39 & 0.89 \\
5 & It helps me to complete assignment within schedule & $47(51.6)$ & $35(38.5)$ & $5(5.5)$ & $2(2.2)$ & 3.35 & 0.86 \\
\hline
\end{tabular}

Table 8. Performance measurement of library person in University of Lagos.

\begin{tabular}{ccccccccc}
\hline S/N & Question & Excellent & Very Good & Good & Fair & Poor & Mean & S.D \\
\hline 1 & Punctuality at work & $62(68.1)$ & $23(25.3)$ & $4(4.4)$ & $1(1.1)$ & & 4.57 & 0.79 \\
2 & Leadership Quality & $46(50.5)$ & $29(31.9)$ & $10(11.0)$ & $3(3.3)$ & $1(1.1)$ & 4.20 & 1.08 \\
3 & Quality of work output & $43(47.3)$ & $32(35.2)$ & $12(13.2)$ & $2(2.2)$ & & 4.20 & 1.00 \\
4 & Dependability and honesty & $48(50.5)$ & $27(29.7)$ & $13(14.3)$ & $2(2.2)$ & $1(1.1)$ & 4.19 & 1.07 \\
5 & Efficient and effective use of resources & $44(48.4)$ & $32(35.2)$ & $10(11.0)$ & $1(1.1)$ & & 4.17 & 1.15 \\
6 & Communication skills & $40(44.0)$ & $36(39.6)$ & $8(8.8)$ & $3(3.3)$ & $1(1.1)$ & 4.12 & 1.13 \\
7 & Creative and Innovative ability & $38(41.8)$ & $37(40.7)$ & $9(9.9)$ & $1(1.1)$ & & 4.03 & 1.27 \\
8 & Team building & $35(38.5)$ & $34(37.4)$ & $14(15.4)$ & $5(5.5)$ & $1(1.1)$ & 4.00 & 1.10 \\
9 & Interpersonal relationship & $37(40.7)$ & $30(33.0)$ & $18(19.8)$ & $1(1.1)$ & $1(1.1)$ & 3.97 & 1.21 \\
10 & Problem solution ability & $36(39.6)$ & $31(34.1)$ & $13(14.3)$ & $3(3.3)$ & $2(2.2)$ & 3.85 & 1.38 \\
\hline
\end{tabular}

\section{Conclusion}

Training works with motivation and without the library personnel being motivated, the tasks and jobs would not be carried out effectively. Hence training of library personnel helps to increase productivity, increase employee morale, availability of skilled workforce, reduce supervision, bring personal growth, and many more. Therefore, library personnel must be motivated to perform well in their jobs by giving them regular training programs that relate to their individual work activities as this will translate in their job output not as individual workers but to the benefit of the organization as well.

\section{References}

[1] Muchinsky, P.M. (2003) Psychology Applied to Work. 7th Edition, Wadsworth, Belmont.

[2] Saetang, J., Sulumnad, K., Thampitak, P. and Sungkaew, T. (2010) Factors Affecting Perceived Job Performance Among Staff: A Case Study of Ban Karuna Juvenile Vocational Training Centre for Boys. The Journal of Behavioral Science, 5, 33-45.

[3] Cole, G.A. (2002) Personnel and Human Resource Management. 5th Edition. Continuum Publisher, London.

[4] De Cenzo, D.A. and Robbins, S.P. (1996) Human Resource Management. John Wiley and Sons, New York.

[5] Baumeister, R.F. and Voh, K.D. (2004) Handbook of Self-Regulation: Research Theories and Applications. Guilford Press, New York.

[6] Adeyemo, D.A. (1999) Relative Influence of Gender Working Experience on Job Satisfaction of Primary School Teachers. The Primary School Educators, 1, 86-89.

[7] Akpa, V.O. (2010) Factors that Motivate Employees to Work: A Case Study of Northern Luzon Adventist College, Pangasinan, Philippines. VDM Verlag Dr. Müller, Saarbrücken, 23. 
[8] Akpa, V.O. (2010) Factors that Motivate Employees to Work: A Case Study of Northern Luzon Adventist College, Pangasinan, Philippines. VDM Verlag Dr. Müller, Saarbrücken, Germany, 43-56.

[9] Yalokwu, P.O. (2006) Fundamentals of Management. 2nd Edition. African Center for Management and Education, Lagos.

[10] Iqbal, S.M.J., Nabi, A.A., Muneer, S. and Anuar, M.A. (2013). Impact of Training on Expectation of Employee and Employer: A Comparative Study. Information Management and Business Review, 5, 601-607.

[11] Yalokwu, P.O. (2006) Fundamentals of Management. 2nd Edition, African Center for Management and Education, Lagos.

[12] Madukoma, E. and Nwosu, J.C. (2011) Job Performance of Library Staff and the Role of Training and Development in Selected Universities in Ogun State, Nigeria. Cotonou Journal of Research Development, 1, 72-89.

[13] Obi, R.C. and Zakari, M. (2008) Employee Training and Development: The Tool for Self-Reliance and Sustainable Development. International Journal of Social and Policy Issues, Development Universal Consortia, 3, 203-211.

[14] Dawha, E.M.K. (2009) Assessment of Personnel Training Needs in the Ibrahim Babangida Library, Federal University of Technology, Yola, Nigeria. Library Philosophy and Practice. http://unilib.unl.edu/LPP/abba2.htm

[15] American Association of Law Libraries (2013) Careers. http://careers.aallnet.org/jobs/5525525/library-assistant

[16] Hackett, P. (1989) Success in Management Personnel. Murray, New York.

[17] Abonam, N.D. (2011) The Role of Motivation on Employee Performance in the Public Sector: A Case Study of the University for Development Studies, WA Campus. Thesis, Institute of Distance Learning, Kwame Nkrumah University of Science and Technology, in Partial Fulfillment of the Requirement for the Degree Bachelor of Arts.

[18] Stueart, R.D. and Moran, B.B. (2007) The Human Resource Function in the Library. Library and Information Center Management. 7th Edition, Libraries Unlimited, London.

[19] Akpa, V.O. (2010) Frederick Herzberg's Two-Factor Theory: Implications for Today’s Organizations. Journal of Management and Organizational Behaviour, 1, 108.

[20] Campbell, J.P. (1990) Modeling the Performance Prediction Problem in Industrial and Organizational Psychology. In: Dunnette, M.D. and Hough, L.M., Eds., Handbook of Industrial and Organizational Psychology, Consulting Psychologists Press, Palo Alto.

[21] Yaya, J.A. (2007) Job Motivation and Emotional Intelligence as Correlates to Librarian’s Job Performance in Selected University Libraries in South West, Nigeria. In Yaya, J.A. and Achonna, A.U. and Osisanwo, T. (2014) Unpublished MLIS dissertation submitted to the department of Library, Archival and Information Studies (LARIS), University of Ibadan, Oyo State. Competitive Intelligence: A Tool for Effective Job Performance in Academic Library. Sky Journal of Educational Research, 2, 20-21.

[22] Johari, J. and Yahya, K.K. (2009) Linking Organizational Structure, Job Characteristics and Job Performance Construct: A Proposed Framework. International Journal of Business Management, 4, 145-152. http://dx.doi.org/10.5539/ijbm.v4n3p145

[23] Afful-Broni, A. (2012) Relationship between Motivation and Job Performance of the University of Mines and Technology, Tarkwa, Ghana: Leadership Lessons. Scientific Research.

[24] Iqbal, S.M.J., Nabi, A.A., Muneer, S. and Anuar, M.A. (2013) Impact of Training on Expectation of Employee and Employer: A Comparative Study. Information Management and Business Review, 5, 601-607. 